\title{
INVESTIGATION OF THE INFLUENCE OF THE PROCESS OF FREEZING ON MICROBIOLOGICAL FACTORS OF SAFETY OF FROZEN SEMI-PRODUCT FOR COOKING DRINK SMOOTHIE
}

\author{
Dmytro Odarchenko \\ Department of commodity science, quality management and ecological safety \\ Kharkiv State University of Food Technology and Trade \\ 333 Klochkivska str., Kharkiv, Ukraine, 61051 \\ laboratory119@mail.ru \\ Andrey Odarchenko \\ Department of commodity science, quality management and ecological safety \\ Kharkiv State University of Food Technology and Trade \\ 333 Klochkivska str., Kharkiv, Ukraine, 61051 \\ 3494545@ukr.net \\ Evgenia Sokolova \\ Department of commodity science, quality management and ecological safety \\ Kharkiv State University of Food Technology and Trade \\ 333 Klochkivska str., Kharkiv, Ukraine, 61051 \\ evgenia-sokolova@ukr.net \\ Vladimir Mikhailik \\ Department of commodity science, quality management and ecological safety \\ Kharkiv State University of Food Technology and Trade \\ 333 Klochkivska str., Kharkiv, Ukraine, 61051 \\ vladimir119@mail.ru
}

\begin{abstract}
A semi-product for cooking a smoothie drink was chosen as a subject of the study. It included strawberries, dried apples and oat flocks. A sample was frozen in a low-temperature calorimeter to $-20^{\circ} \mathrm{C}$. It was established, that freezing at-20 $\pm 2{ }^{\circ} \mathrm{C}$ favors the full conservation of a sample and storage during 270 days. The results of the organoleptic evaluation of the semi-product before freezing and after refrigeratory storage during 270 demonstrated that the product is characterized by a high quality.

Microbiological parameters of the fresh and frozen semi-product were studied for a quantity of mesophilic aerobic and facultative-anaerobic microorganisms (QMAFMAnM). And also for bacteria of the colibacillus group (BGCB), pathogenic microorganisms of bacteria of Salmonella genus, molds and yeast. The gram-negative microflora - bacteria of the colibacillus group, pathogenic microorganisms including bacteria of Salmonella genus, were not observed in samples of frozen semi-products.

The studies demonstrated freezing advantages from both aspects of minimization of losses of valuable biocomponents of the raw material and of achieving high organoleptic parameters of products after freezing and defrosting. The observance of optimal conditions of freezing excludes the necessity of the additional use of artificial preservatives, provides high-quality products and safety that corresponds to all principles of healthy nutrition.
\end{abstract}

Keywords: frozen products, safety, microbiological pollution, gram-negative microflora, low-temperature storage, smoothie.

(C) Dmytro Odarchenko, Andrey Odarchenko, Evgenia Sokolova, Vladimir Mikhailik

\section{Introduction}

For improving health of the Ukrainian population, it is extremely important to provide full-value and healthy nutrition. Continuous supply of the population with quality and safety products of the vegetable origin is one of most important tasks of the Ukrainian agroinsdustrial complex [1].

The growth of the food culture of the population, growth of demand for food products, manifested as healthy ones, understanding of connections between the food structure and health 
condition, undoubtedly, will provide the popularity of frozen fruits and berries among consumers. For this aim, it is necessary to develop new technologies, which use allows to get frozen products, which quality is not worse than one of initial raw materials.

Creation of alcohol-free drinks using vegetable raw materials - smoothies becomes more and more popular throughout the world. The choice of components for preparing a smoothie drink is rather wide. The recipe composition of the drink may include fresh, frozen, dried fruits, vegetables and berries, and also different spices, bran, groats, milk products. Depending on used components, smoothie may be both juice and a main dish or dessert.

At storage fresh fruits and vegetables are easily subjected to the influence of mechanic factors, injurious insects and pathogenic microbes, fast spoilage, caused by native microbial enzymes due to the life activity of microorganisms [2]. One of ways of preserving food products is freezing that guarantees the high quality level of products during the long storage. The essence of freezing is in the inhibiting effect of cold on the microflora development that is one of important causes of spoilage of vegetable products [3]. The study of an influence of the effect of low temperatures on the life activity of microorganisms is scientifically important for the refrigeratory technology.

At producing frozen fruit semi-products, the great attention is paid to the microbiological pollution of vegetable raw materials and observance of sanitary-hygienic production conditions $[4,5]$. For providing optimal conditions that limit the growth of microorganisms and getting products of the proper quality, it is necessary to study microbiological processes that take place in food products [6]. Based on it, there was formulated the aim of the work that is in the investigation of the freezing process effect on microbiological quality parameters of a semi-product of puree-like mixture of dried apples, strawberries, sugar and oat flocks for cooking a smoothie drink, stored during 270 days at the temperature $-18 \pm 2{ }^{\circ} \mathrm{C}$. It will allow to widen the assortment of frozen products, to increase their storage life and to keep healthy properties and tastes.

\section{Materials and Methods}

A semi-product with the weight $200 \mathrm{~g}$ for cooking a smoothie drink was chosen as an object of the study. The technological scheme of production looks as following: 100 of dried apples of "Borovinka" variety, planted in Ukraine, were washed, blanched in boiling water during 3 ...5 min. Strawberries of the middle-early "Dukat" variety, planted in Ukraine in the amount of $70 \mathrm{~g}$ were inspected, washed, cleaned from fruit stems. $10 \mathrm{~g}$ of sugar, made by "Astarta-Kiev" and $30 \mathrm{~g}$ of oat flocks "Hercule", made by "Diamond LTD" in Ukraine, were added. The prepared components were comminuted by the mechanical way to particles with the size $38,114 \cdot 10^{-5} \mathrm{~m}$.

Strawberries contain many nutrients that condition their food and dietic value, including carbohydrates, represented by the high content of sugars (up to $12 \%$ ). The content of cellulose in strawberries is $4,0 \%$, proteins are near $1 \%$, that is a source of irreplaceable amino acids. Lipids are presented by saturated and unsaturated fatty acids. Strawberries contain many macro- and microelements, vitamins.

Dried apples have a rich chemical composition. Their high energetic value is conditioned by the increased quantity of carbohydrates (57,2\%). Dried apples have a rich vitamin composition - vitamin $\mathrm{B}_{4}(17,6 \mathrm{mg})$ and vitamin $\mathrm{C}(3,9 \mathrm{~g})$. As to macroelements, dried fruits contain much potassium $(580 \mathrm{mg})$, phosphorus $(77 \mathrm{mg})$, magnesium $(30 \mathrm{mg})$, calcium $(111 \mathrm{mg})$ and sodium (87 $\mathrm{mg})$, and also many microelements.

The chemical composition of oat flocks contain protein substances up to $12,5 \%$, fats up to $6 \%$, carbohydrates up to $66,5 \%$, ash up to $4,0 \%$, cellulose up to $12,2 \%$, water $12 \%$. Oat flocks exceed other groats by the amount of proteins $(13,1 \mathrm{~g})$, they contain all amino acids, irreplaceable for the organism. Their mineral and vitamin composition is presented by the wide assortment of substances, necessary for the human organism.

Freezing was realized using the experimental set - low-temperature colorimeter, made by own hands and patented by scientists of the Kharkov state university of economy and trade, made in the Institute of cryobiology and cryomedicine, NAS of Ukraine [7]. The calorimeter allows to regulate the temperature and speed of freezing and also to register the temperature of samples, used 
in the further analysis, continuously. Liquid nitrogen vapor was used as a cold carrier. The scheme of this set is presented on Fig. 1.

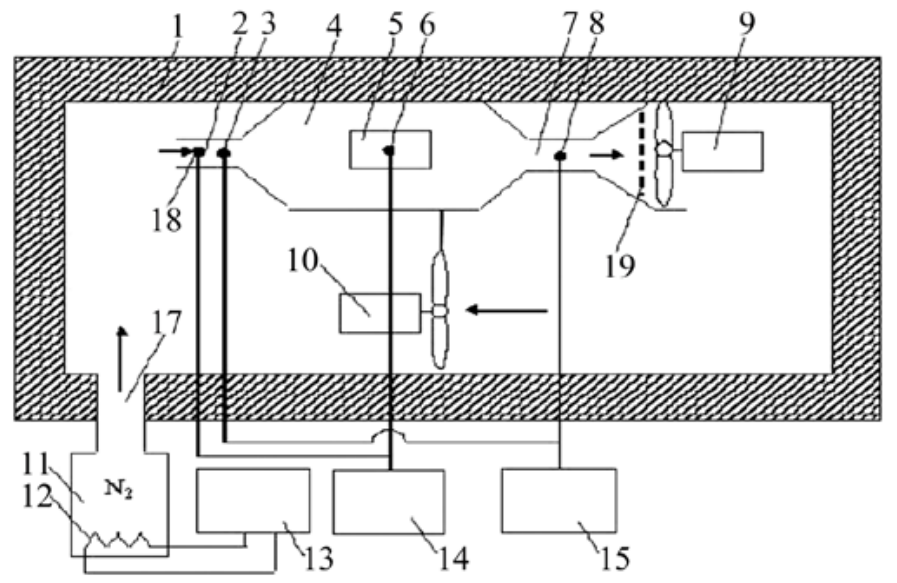

Fig. 1. The scheme of low-temperature calorimeter for freezing: 1 - coat; 2, 7 - input and output orifices of the measuring chamber; 3,8 - junctions of the differential thermocouple;

4 - measuring chamber; 5 - studied object; 6,17 - junctions of thermocouples; 9,10 - ventilators;

11 - Dewar vessel; 12 - heater; 13 - autotransformer; 14, 15 - electric recorders; 16 - input orifice; 18 - damper

The principle of the work of the set is following: nitrogen vapor comes into the coat by the heater, placed in Dewar vessel 11. The temperature in the coat depends on the speed of nitrogen evaporation that, in its turn, is determined by the power of the heater 12 . It gives a possibility to widen the diapason of working temperatures to values, close to the one of liquid nitrogen. As a result of the work of the ventilator 9 , nitrogen vapor pass through the measuring chamber 4 , where they absorb heat, excreted by the object. The temperature difference is fixed at the input and output by the continuous recorder 15 by the differential thermocouple. The area under the curve is the dependence of the temperature difference from the time, proportional to the amount of heat, excreted by the object at reaching the coat temperature. Such calorimeter gives a possibility to get distinct results, quality characteristics and wide spectrum of temperatures [8].

Microbiological parameters of the fresh and frozen semi-product were studied for a quantity of mesophilic aerobic and facultative-anaerobic microorganisms (QMAFMAnM). And also for bacteria of the colibacillus group (BGCB), pathogenic microorganisms of bacteria of Salmonella genus, molds and yeast.

The studies were realized by the plate method of quantitative account on solid nutrient mediums. The total amount of bacteria was determined on meat - peptonic agar. Inoculations on meat-peptonic agar were thermostated at the temperature $30{ }^{\circ} \mathrm{C}$ during 72 hours [9]. For determining bacteria of the colibacillus group [10] inoculations were realized on Kessler medium, thermostated during 48 hours at temperature $37^{\circ} \mathrm{C}$. Salmonella bacteria [11] were studied by inoculating on the selenitic medium, thermostated during $2 \ldots 48$ hours at the temperature $37^{\circ} \mathrm{C}$, with reinoculation on Ploskirev's medium. For finding molds and yeast, inoculations in dishes with wort agar medium were incubated at the temperature $28{ }^{\circ} \mathrm{C}$ during 5-7 days [12]. Parameters were determined in the average sample of the newly-prepared specimen and at refrigeratory storage during 30, 60, 90, 180 and 270 days.

The studies were conducted in the laboratory of medical-biological products in the Kharkiv State University of Food Technology and Trade in Ukraine.

\section{1. Experimental procedures}

Freezing was conducted on the studied sample of the semi-product as comminuted homogenous mass in the amount $20 \mathrm{~g}$, placed in the colorimeter with the given medium temperature 
$-20^{\circ} \mathrm{C}$. After that it was stored in the freezing room during 270 days (because the maximal storage term of these season products is $270-360$ days) at the temperature $-18 \pm 2{ }^{\circ} \mathrm{C}$, because the complete conservation of products takes place at this temperature.

Organoleptic parameters of the semi-product were studied before and after freezing by the gustatory commission of the department of commodity, quality management and safety of Kharkiv State University of Food Technology and Trade (Ukraine) consisting of 10 persons. 5-point system, presented in gustatory lists, was used for the point estimation of the semi-product quality. Each parameter (consistence, color, taste, smell) of scales had 5 quality degrees, expressed in points in Table 1.

Table 1

Point estimation of the semi-product quality

\begin{tabular}{|c|c|c|}
\hline Parameters & Quality characteristic & Points \\
\hline \multirow{3}{*}{ Consistence } & Homogenous with evenly distributed finely comminuted pulp & 5 \\
\hline & $\begin{array}{l}\text { Insufficiently homogenous, with inessential delamination as a result of } \\
\text { sedimentation of pulps fractions }\end{array}$ & $3-4$ \\
\hline & Uneven, pulp forms a sediment & $1-2$ \\
\hline \multirow{3}{*}{ Color } & $\begin{array}{l}\text { Bright, even along whole mass, correspondent to the color of the used } \\
\text { fruits and berries }\end{array}$ & 5 \\
\hline & $\begin{array}{l}\text { Insufficiently bright, doesn't completely correspond to the color of the } \\
\text { used components }\end{array}$ & $3-4$ \\
\hline & Unusual for this type of products & $1-2$ \\
\hline \multirow{3}{*}{ Taste } & Brightly expressed, pleasant, harmonic & 5 \\
\hline & Pleasant, corresponds to this type of products, without side tastes & $3-4$ \\
\hline & Non-expressed & $1-2$ \\
\hline \multirow{3}{*}{ Smell } & Pleasant, brightly expressed, without side smells & 5 \\
\hline & Weakly expressed, without side smells & $3-4$ \\
\hline & Non-expressed & $1-2$ \\
\hline
\end{tabular}

The results of the organoleptic estimations are presented in Table 2.

Table 2

Changes of organoleptic parameters of the semi-product

\begin{tabular}{ccc}
\hline Parameters & Before freezing & After refrigeratory storage during 270 days \\
\hline Consistence & $\begin{array}{c}\text { Homogenous with evenly distributed finely } \\
\text { comminuted pulp }\end{array}$ & $\begin{array}{c}\text { Homogenous with evenly distributed finely commi- } \\
\text { nuted pulp }\end{array}$ \\
Color & $\begin{array}{c}\text { Bright, even along whole mass, correspondent to } \\
\text { the color of the used fruits and berries }\end{array}$ & $\begin{array}{c}\text { Bright, even along whole mass, correspondent to the } \\
\text { color of the used fruits and berries } \\
\text { Taste }\end{array}$ \\
Smell & Pleasant, brightly expressed, & Pleasant, brightly expressed, without side tastes \\
& Pleasant, brightly expressed, without side smells & Pleasant, without side tastes
\end{tabular}

\section{Results}

The results of the organoleptic estimation demonstrated the high quality of the product. The consistence of the semi-product was homogenous with evenly distributed finely comminuted pulp before and after comminution. After defrosting the color remained bright, even along the whole mass. The taste and smell are brightly expressed, pleasant and harmonic. 
The list of groups of microorganisms that must be normalized in food products is determined, based on their recipe and chemical composition, production technology, conditions and terms of storage. Microbiological parameters are an inseparable part of the complex estimation of the quality and safety of food products [13].

At producing the frozen semi-product, the great attention is paid to the microbiological pollution of vegetable raw materials and observance of sanitary-hygienic production conditions. The resistance of a microbial cell in frozen products depends on the freezing speed, final temperature, storage duration, specific composition of the microflora, microbiological pollution level, and $\mathrm{pH}$ of the medium. At the initial freezing stage the number of bacterial cells decreases fast, then the death of microorganisms decelerates.

For determining microbiological parameters, their effect and changes at storage, the studies were conducted directly after producing, then in 30, 60, 90, 180 and 270 days of refrigeratory storage at the temperature $-18 \pm 2{ }^{\circ} \mathrm{C}$.

The number of MAFAnM before freezing were $1,2 \times 10^{3}$, after 30 days $8,7 \times 10^{2}$, after 60 and 90 days $7,5 \times 10^{2}$, and after 180 and 270 days of refrigeratory storage at the temperature $-18 \pm 2{ }^{\circ} \mathrm{C}$ decreased to $6,3 \times 10^{2}$ comparing with the newly-produced one. Before freezing the index of yeast number was $1,3 \times 10^{2}$, after 30 days $-9,3 \times 10,60$ days $-9,1 \times 10,90$ and180 days $-8,7 \times 10$, after 270 days of storage it decreased to $8,5 \times 10$. The index of molds in the newly-produced semi-product was $8 \times 10$, after storage during 30, 60 days decreased to $6,8 \times 10$, after 90 and 180 days - to $6,7 \times 10$, after 270 days this index decreased to $6,4 \times 10$.

The gram-negative microflora - bacteria of the colibacillus group, pathogenic microorganisms including bacteria of Salmonella genus, were not observed in samples of frozen semi-products. The microbiological safety of these semi-products mainly depends on pollution of the raw materials, sanitary-hygienic production conditions and the speed of realizing preparatory operations; freezing and low-temperature storage, in their turn, essentially inhibit the life activity of microorganisms, causing the high level of sanitary-hygienic and epidemiological safety during the whole storage period. The degree of seeding and specific composition of the microflora not only characterize the quality of the ready product, but also allow to judge about undesirable processes that may appear at its storage.

\section{Conclusions}

The obtained results testify that:

1. Freezing of the semi-product of fruits and berries at correct temperatures allows to use it year-round. This processing method is one of promising, allows to use the frozen semi-product for preparing drinks.

2. There was established the decrease of total microbiological pollution during refrigeratory storage that testifies to the negative influence of cold on the life activity of microorganisms. The amount of MAFAnM after 30, 60, 90, 180 and 270 days of refrigerator storage at the temperature $-18 \pm 2{ }^{\circ} \mathrm{C}$ decreases comparing with the newly-produced one. The amount of yeast and molds also decreases at storage, but the complete extinction of the microflora doesn't take place, so it is important to observe sanitary-hygienic norms at their production, package, storage and realization. The obtained data confirm the safety and quality of consuming the semi-product during 270 days.

Freezing inhibits the development of microorganisms, so the necessity of using preservatives and other artificial additives is excluded.

3. The described technology of the frozen semi-product for cooking a smoothie drink will allow to widen the assortment of frozen products, to increase their storage life and to keep healthy properties and tastes. The use of frozen semi-products at trade enterprises, hotel-restaurant business and everyday life favors the better organization of the staff work, economy of productive resources, decreasing time for cooking drinks.

\section{References}

[1] Svystun, T., Tuz, K. (2017). Market analysis of semi-frozen of Ukraine. Economy of food industry, 9 (2), 19-23. 
[2] Zahrebelniy, V. O. (2015). The main aspects of the evaluation of microbiological risk of food. Veterinary Biotechnology, 26, 83-89.

[3] Afroz, H., Ahmed, T., Uddin, M. A. (2016). Microbiological analysis and antibacterial activity of pear samples. Stamford Journal of Microbiology, 5 (1), 1-4. doi: 10.3329/sjm.v5i1.26910

[4] Korzun, V. N., Tikhonenko, Yu. S. (2010). Functional products and their role in human nutrition. Scientific works ONACHT, 2 (38), 173-178.

[5] Serdyuk, M., Stepanenko, D., Baiberova, S., Gaprindashvili, N., Kulik, A. (2016). Substantiaton of selecting the method of pre-cooling of fruits. Eastern-European Journal of Enterprise Technologies, 4 (11 (82)), 62-68. doi: 10.15587/1729-4061.2016.76235

[6] Fatema, N., Acharjee, M., Noor, R. (2013). Microbiological Profiling of Imported Apples and Demonstration of Bacterial Survival Capacity through in vitro Challenge Test. American Journal of Microbiological Research, 1 (4), 98-104. doi: 10.12691/ajmr-1-4-6

[7] Odarchenko, A. M., Pogozhykh, M. I., Odarchenko, D. M. (2006). Pat. No. 13953 UA. Device to determine the amount of free and bound water at temperatures close to the temperature of liquid nitrogen. MPK A23L 1/00. No. u200511091; declareted: 23.11.2005; published: 17.04.2006, Bul. No. 4.

[8] Cherevko, O., Odarchenko, A., Pogozhikh, N., Odarchenko, D., Sokolova, E. (2016). Effect of sautéing of onion on its storage at low temperatures. Eastern-European Journal of Enterprise Technologies, 5 (11 (83)), 46-50. doi: 10.15587/1729-4061.2016.81391

[9] GOST 10444.15-19. Food products. Methods for determining the amount of mesophilic aerobic and facultative-anaerobic microorganisms (1994). Moscow: Publishing Standards, 13.

[10] GOST 30518. Food products. Methods for detecting and determining the number of bacteria of the group of E. coli bacteria (coliform bacteria) (2005). Moscow: Publishing Standards, 8 .

[11] GOST 30519. Food products. Methods for the detection of bacteria of the genus Salmonella (2005). Moscow: Publishing Standards, 10.

[12] GOST 10444.12-88. Food products. Methods for the determination of yeasts and molds (2010). Moscow: Standartinform Publishing, 8.

[13] DSTU 6029:2008. Fruit and berry semi-finished products (crushed and mashed potatoes) quick-frozen (2009). Kyiv: Derzhspozhyvstandart of Ukraine, 18.

\title{
INVESTIGATION OF THE MOISTURE-RETAINING POWER OF RYE-WHEAT GLUTEN AND FLOUR WITH POLYFUNCTIONAL FOOD SUPPLEMENT "MAGNETOFOOD"
}

\author{
Iryna Tsykhanovska \\ Department of food and chemical technologies \\ Ukrainian Engineering-Pedagogics Academy \\ 16 Universitetska str., Kharkiv, Ukraine, 61003 \\ cikhanovskaja@rambler.ru \\ Victoria Evlash \\ Department of Chemistry, Microbiology and Food Hygiene \\ Kharkiv State University of Nutrition and Trade \\ 333 Klochkivska str., Kharkiv, Ukraine, 61051 \\ evlashvv@gmail.com \\ Alexandr Alexandrov \\ Department of food and chemical technologies \\ Ukrainian Engineering-Pedagogics Academy \\ 16 Universitetska str., Kharkiv, Ukraine, 61003 \\ alexandrov.a.v.a.v@gmail.com
}

